University of Nebraska - Lincoln

DigitalCommons@University of Nebraska - Lincoln

Publications from USDA-ARS / UNL Faculty

U.S. Department of Agriculture: Agricultural

Research Service, Lincoln, Nebraska

6-1-1987

\title{
Dryland Maize Development and Yield Resulting From Tillage and Nitrogen Fertilization Practices
}

\author{
Wallace Wilhelm \\ University of Nebraska-Lincoln, wwilhelm1@unl.edu \\ James S. Schepers \\ University of Nebraska-Lincoln, james.schepers@gmail.com \\ M. L. Mielke \\ USDA-ARS \\ John W. Doran \\ University of Nebraska-Lincoln, jdoran1@unl.edu \\ James R. Ellis \\ University of Nebraska-Lincoln, jellis3@unl.edu \\ See next page for additional authors
}

Follow this and additional works at: https://digitalcommons.unl.edu/usdaarsfacpub

Part of the Agricultural Science Commons

Wilhelm, Wallace; Schepers, James S.; Mielke, M. L.; Doran, John W.; Ellis, James R.; and Stroup, Walter W., "Dryland Maize Development and Yield Resulting From Tillage and Nitrogen Fertilization Practices" (1987). Publications from USDA-ARS / UNL Faculty. 118.

https://digitalcommons.unl.edu/usdaarsfacpub/118

This Article is brought to you for free and open access by the U.S. Department of Agriculture: Agricultural Research Service, Lincoln, Nebraska at DigitalCommons@University of Nebraska - Lincoln. It has been accepted for inclusion in Publications from USDA-ARS / UNL Faculty by an authorized administrator of DigitalCommons@University of Nebraska - Lincoln. 


\section{Authors}

Wallace Wilhelm, James S. Schepers, M. L. Mielke, John W. Doran, James R. Ellis, and Walter W. Stroup 


\title{
Dryland Maize Development and Yield Resulting From Tillage and Nitrogen Fertilization Practices ${ }^{1}$
}

\author{
W.W. WILHELM, J.S. SCHEPERS, L.N. MIELKE, J.W. DORAN, J.R. ELLIS and W.W. \\ STROUP \\ ARS, USDA, Soil and Water Conservation Research Unit and Biometrics and Information \\ Center, University of Nebraska-Lincoln, Lincoln, NE 68583 (U.S.A.)
}

(Accepted for publication 5 March 1987)

\begin{abstract}
Wilhelm, W.W., Schepers, J.S., Mielke, L.N., Doran, J.W., Ellis, J.R. and Stroup, W.W., 1987. Dryland maize development and yield resulting from tillage and nitrogen fertilization practices. Soil Tillage Res., 10: 167-179.

Conservation tillage ( $>30 \%$ residue cover) has proven to be very effective in reducing runoff and erosion and in increasing soil water storage. In dryland cropping situations, the latter fact should result in a greater yield potential for conservation than for conventional tillage. In practice, however, this theoretical advantage has not consistently realized. The objective of this study was to determine the influence of tillage and $\mathrm{N}$-fertilization management on growth and yield of maize (Zea mays L.) under dryland conditions in the western Corn Belt (U.S.A.). The experiment was conducted from 1977 through 1983 on a Crete-Butler silty clay loam (Pachic Argiustolls-Abruptic Argiaquolls). Whole-plot treatments were moldboard plow, disk, chisel plow, no-till, disk plus manure and no-till plus manure. Sub-plot treatments were $\mathrm{N}$ fertilization $\left(\mathrm{NH}_{4} \mathrm{NO}_{3}\right)$ at 0,70 or $140 \mathrm{~kg} \mathrm{ha}^{-1} \mathrm{~N}$. Grain yield and yield components were not affected by the tillage $\times \mathrm{N}$-fertilization interaction. The response both to tillage and to $\mathrm{N}$ fertilization was influenced by yearly climatic variation. Generally, grain yield was maximum at $90 \mathrm{~kg} \mathrm{ha}^{-1} \mathrm{~N}$ and, in dry years, yields usually declined at $\mathrm{N}$ rates $>90 \mathrm{~kg} \mathrm{ha}^{-1} \mathrm{~N}$. In only one year (1978) did tillage influence yield; the chisel plow treatment produced less grain than the moldboard plow or disk. The no-till treatment did not differ from the mean of the other 3 tillage practices in any year. The interaction of yearly weather variation with phenology and the development of the crop appeared to be a greater determinant of yield than tillage.
\end{abstract}

\section{INTRODUCTION}

Conservation tillage is defined as any tillage and planting system that retains at least $30 \%$ crop-residue cover on the soil surface after planting (Bauder,

\footnotetext{
'Paper presented at the 10th Conference of ISTRO, 8-12 July 1985, at Guelph, Canada. Contribution from the Agricultural Research Service, U.S. Department of Agriculture, in cooperation with the Nebraska Agricultural Research Division, University of Nebraska-Lincoln, Lincoln, NE 68583, U.S.A., Journal Series No. 8060.
} 
1984). These crop-management practices have proven very successful in reducing runoff and erosion (Onstad, 1972; Harrold and Edwards, 1972) and in increasing soil water storage (Blevins et al., 1971; Johnson et al., 1984). These facts may be a direct result of greater infiltration of water associated with conservation tillage (Baeumer and Bakermans, 1973; Mielke et al., 1984).

In dryland ( rain-fed) cropping situations, enhanced water storage from conservation tillage results, theoretically, in greater yield potential than in conventional tillage systems. In practice, however, this theoretical advantage in increased crop yield has not been consistently realized (Triplett, 1982). Jones et al. (1968), Shanholtz and Lillard (1969) and van Doren and Triplett (1973) reported increased crop growth and yield with reduced tillage, and attributed the increased productivity to increased water storage and availability with reduced-tillage systems. Olson and Shoeberl (1970) found no differences in crop yields with various tillage systems when drought stress occurred during pollination. They suggested that, under severe drought conditions, residue mulch was not as effective in conserving soil water as under short-term stress periods. In a more humid climate, van Doren and Triplett (1973) indicated that grain-yield differences between conventional and no-till systems were small when rainfall was below normal.

As indicated above, the tillage method frequently affects the soil physical environment, which subsequently may influence the phenological development of the crop. Differences in phenology and dry-matter partitioning between vegetative and reproductive tissues may be related to differences in soil water and temperature regimes. Plant total dry-matter production and grain yield are closely associated. Relationships and functions have also been developed, to allow standardized comparisons of rates of crop growth over different environments. These functions are collectively termed growth analysis. Rate of dry-matter assimilation (net assimilation rate, NAR) and leaf area index (LAI) combine to give a measure of rate of dry-matter accumulation (crop growth rate, CGR) (Hunt, 1978).

Generally, growth analysis functions have been calculated using days as the measure of time. However, Russelle et al. (1984) suggested degree days (heat unit) as a more functional basis, because variation in crop phenological development from year-to-year, or treatment-to-treatment, caused by differences in heat unit accumulation was eliminated. Comparisons on a heat-unit basis would automatically compensate for variation in phenological stage. One exception to this concept would be if temperature were the variable being tested. Use of degree days would, therefore, remove the effect of the treatment.

The purpose of this study was to evaluate the effect of various tillage-management practices on maize (Zea mays L.) under dryland conditions. Emphasis was placed on evaluating maize response in terms of leaf-area development, dry-matter accumulation and grain yield. 


\section{TABLE I}

Physical and chemical properties of Crete-Bulter silty clay loam (fine, montmorillonitic, mesic, Pachic Arguistolls-Abruptic Argiaquolls) at Lincoln, NE, U.S.A.

\begin{tabular}{|c|c|c|c|c|c|}
\hline \multirow{2}{*}{$\begin{array}{l}\text { Depth } \\
\text { (m) }\end{array}$} & \multirow[t]{2}{*}{$\mathrm{pH}^{\mathrm{a}}$} & \multicolumn{3}{|c|}{ Particle size fraction $(\%, \mathrm{w} / \mathrm{w})$} & \multirow{2}{*}{$\begin{array}{l}\text { Bulk } \\
\text { density } \\
\left(\mathrm{Mg} \mathrm{m}^{-3}\right.\end{array}$} \\
\hline & & Sand $^{b}$ & Silt $^{c}$ & Clay $^{d}$ & \\
\hline $0-0.30$ & 5.3 & 12 & 53 & 35 & 1.32 \\
\hline $0.30-0.60$ & 5.9 & 11 & 44 & 45 & 1.48 \\
\hline $0.60-0.90$ & 6.3 & 10 & 46 & 44 & 1.45 \\
\hline $0.90-1.20$ & 6.5 & 9 & 51 & 40 & 1.38 \\
\hline $1.20-1.50$ & 6.7 & 10 & 54 & 36 & 1.37 \\
\hline $1.50-1.80$ & 6.8 & 10 & 54 & 36 & 1.36 \\
\hline
\end{tabular}

${ }^{a}$ Values determined in $1: 1(\mathrm{v}: \mathrm{v})$ mixture of soil to water.

${ }^{\text {bParticles }}>50 \mu \mathrm{m}$.

'Particles 2-50 $\mu \mathrm{m}$.

${ }^{\mathrm{d}}$ Particles $<2 \mu \mathrm{m}$.

\section{MATERIALS AND METHODS}

The experiment was conducted at the Agronomy Research Farm, Lincoln, NE, U.S.A., on a Crete-Butler silty clay loam (fine, montmorillonitic, mesic, Pachic Argiustolls-Abruptic Argiaquolls) (Table I). Tillage treatments (whole plots ) were arranged in a randomized complete block, and nitrogen $(\mathrm{N})$ fertilizer rate treatments were assigned to sub-plots. Whole plots were replicated 4 times. Whole plots were $22.9 \times 18.3 \mathrm{~m}$; sub-plots were $22.9 \times 6.1 \mathrm{~m}$. Treatments were repeated on the same experimental unit in successive years. Tillage

\section{TABLE II}

Description of primary and secondary tillage treatments

\begin{tabular}{|c|c|c|c|c|c|}
\hline \multirow[t]{2}{*}{ Tillage treatment } & \multicolumn{3}{|l|}{ Primary tillage } & \multicolumn{2}{|c|}{ Secondary tillage } \\
\hline & Tillage tool & $\begin{array}{l}\text { Width of } \\
\text { implement } \\
(\mathrm{m})\end{array}$ & $\begin{array}{l}\text { Depth } \\
(\mathrm{mm})\end{array}$ & Tillage tool ${ }^{\mathrm{a}}$ & $\begin{array}{r}\text { Depth } \\
(\mathrm{mm})\end{array}$ \\
\hline Plow (PL) & Moldboard plow & 1.22 & 210 & Tandem disk & 100 \\
\hline Disk (DK) & Tandem disk & 4.37 & 100 & Tandem disk & 100 \\
\hline Chisel $(\mathrm{CH})$ & $\begin{array}{l}\text { Chisel plow } \\
\text { (straight shank) }\end{array}$ & 2.03 & 230 & Tandem disk & 100 \\
\hline No-till (NT) & None & - & - & None & - \\
\hline Disk + manure (DM) & Tandem disk & 4.37 & 100 & Tandem disk & 100 \\
\hline No-till + manure (NM) & None & - & - & None & - \\
\hline
\end{tabular}

The same implement (4.37-m wide) was used for all secondary tillage. 
TABLE III

Dates of major cultural practices, 1977-1983, tillage experiment, Lincoln, NE, U.S.A.

\begin{tabular}{|c|c|c|c|c|c|c|c|}
\hline Activity & 1977 & 1978 & 1979 & 1980 & 1981 & 1982 & 1983 \\
\hline Manure application & 28 Apr. & 27 Apr. & 30 Apr. & 15 Apr. & 28 Apr. & 3 May & 16 May \\
\hline Application rate $\left(\mathrm{Mg} \mathrm{ha}^{-1}\right)$ & 51.7 & $26.0^{\circ}$ & 35.2 & 32.2 & 24.1 & 27.1 & 26.8 \\
\hline $\mathrm{N}$ content $\left(\mathrm{g} \mathrm{kg}^{-1}\right)$ & 24 & 14 & 6 & 10 & 11 & 11 & 11 \\
\hline Primary tillage & 28 Apr. & 22 May & 11 May & 16 Apr. & 29 Apr. $^{a}$ & 5 May & 9 May \\
\hline Fertilizer application & 29 Apr. & 22 May & 14 May & $18 \mathrm{Apr}$. & $30 \mathrm{Apr}$ & 3 June & 24 May $^{\mathrm{b}}$ \\
\hline Secondary tillage & 29 Apr. & 24 May & 14 May & $21 \mathrm{Apr}$. & 1 May & 3 June & 25 May \\
\hline Planting & 2 May & 26 May & 15 May & $29 \mathrm{Apr}$. & 1 May & 3 June & 26 May \\
\hline $\begin{array}{l}\text { Seeding rate } \\
\text { (number of seeds } \mathrm{m}^{-2} \text { ) }\end{array}$ & 4.10 & 2.77 & 3.80 & 4.00 & 4.00 & 4.12 & 4.12 \\
\hline Harvest & 10 Oct. & 17 Oct. & 28 Oct. & - & 19 Oct. & 9 Nov. & 3 Nov. \\
\hline
\end{tabular}

${ }^{a}$ Plowing occurred 29 November 1980; other primary tillage, 29 April 1981.

${ }^{b}$ Only $70 \mathrm{~kg} \mathrm{ha}^{-1} \mathrm{~N}$ applied to $140 \mathrm{~kg} \mathrm{ha}^{-1} \mathrm{~N}$ treatment; other treatments unchanged.

treatments used in this study were moldboard plow (PL), tandem disk (DK), chisel plow $(\mathrm{CH})$, no-till (NT), disk plus manure (DM) and no-till plus manure (NM). A full description of tillage and management schedules is given in Tables II and III. Manure was applied on designated treatments by hand, or with a farm spreader, prior to primary tillage each year. Nitrogen fertilizer at rates of 0,70 , or $140 \mathrm{~kg} \mathrm{ha}^{-1} \mathrm{~N}$ was broadcast as $\mathrm{NH}_{4} \mathrm{NO}_{3}$ and incorporated with secondary tillage except in NT and NM treatments. According to soil test, no $\mathrm{P}$ or $\mathrm{K}$ was needed, and none was applied. Maize cultivar Neb 620 was planted from 1977 through 1981; cultivar Neb 611 was planted from 1982 through 1983. In 1977 and 1978, the crop was planted with a Buffalo No-Till planter ${ }^{1}$ (Fleischer Manufacturing, Inc., Columbus, NE, U.S.A.) equipped with 0.36-m sweeps. In 1979, the sweeps were not used. From 1980 through 1983, a Max-Emerge Planter with double-disk openers and "V"-press wheels was used. Seeding depth was $50 \mathrm{~mm}$ for all years.

Pre- and post-emergence surface-applied herbicides were used at labeled rates. The specific herbicides used varied from year to year, but were uniform over the entire experiment within each year. Chemicals used included: alachlor; atrazine; cyanazine; dicamba; glyphosate; metolachlor; paraquat; pendimethalin; 2,4-D. Weeds not controlled by herbicides were hand-weeded. For soil insect control, carbofuran or terbufos was applied at planting at labeled rates over the seed row in a $0.20-\mathrm{m}$ band to control northern maize rootworm (Diabrotica longicornis (Say)). In 1982, carbaryl was applied at $0.91 \mathrm{~kg} \mathrm{ha}^{-1}$ for control of European maize borer (Ostrinia nubilalis Hubner).

\footnotetext{
${ }^{1}$ Mention of products is included for the benefit of the reader, and does not imply endorsement or preferential treatment by the University of Nebraska-Lincoln or by the U.S. Department of Agriculture.
} 
Grain yield was determined in 1977, 1978, 1979 and 1981 by hand harvesting two $7.63-\mathrm{m}$ row segments, removing the kernels from the ears, weighing them and determining the grain water content. No grain was harvested in 1980 because of severe drought. In 1982 and 1983, grain was harvested from two $15.25-\mathrm{m}$ row segments with a plot combine. Grain was weighed and water content determined. Immediately before grain harvest, the number of plants and ears in the harvested row segments was recorded. This information, with seed weight, was used to calculate yield components of plant population, ear population and seeds per plant.

Soil water content was determined by the neutron scatter technique. Total water used for each treatment was calculated by the difference between initial and final water content, plus rainfall, between the initial and final measurement dates.

During the 1977 and 1979 seasons, leaf area and dry matter were measured at about 14-day intervals. At each sampling date, 4 plants were cut at ground level and separated into leaf blade, stem and leaf sheath, and ear components. Green leaf-blade area of fully-collared leaves was determined with a $\mathrm{LiCor} \mathrm{Li}$ 3000 leaf-area meter (Lambda Instruments, Inc., Lincoln, NE, U.S.A.) . Separated tissues were dried at $70^{\circ} \mathrm{C}$ to constant weight and weighed.

Plant dry-matter and leaf-area data were fitted as a function of thermal time with the general equation

$$
Y=\exp \left(b_{0}+b_{1} x+b_{2} x^{2}+b_{3} x^{3}\right)
$$

using PROC NLIN of SAS (SAS, 1982). Growing degree days (GDD) with a $10^{\circ} \mathrm{C}$ base and upper and lower limits of 30 and $10^{\circ} \mathrm{C}$, respectively, were used as the measure of thermal time (Russelle et al., 1984). These functions were used to derive LAI, CGR, NAR and leaf area duration (LAD). Assumptions and limitations defined by Hunt (1978) were observed in these calculations.

Leaf-area, dry-matter and yield-component data were analyzed by standard analysis of variance within each year. Orthogonal contrasts were used to separate treatment means; $\mathrm{N}$ rates were compared using regression analysis.

\section{RESULTS AND DISCUSSION}

Dryland ( rain-fed) crop production is closely linked to the climatic conditions that occur during the growing season. As is common with all continental environments, considerable yearly variation in temperature and precipitation was encountered during the course of this experiment (Table IV). Although average growing-season temperature (April-October) did not fluctuate more than $\pm 1^{\circ} \mathrm{C}$, monthly mean temperatures were as much as $0.9^{\circ} \mathrm{C}$ above normal (August 1983) and $3.2^{\circ} \mathrm{C}$ below normal (April 1983). Departures from monthly mean temperature, both above and below normal within one growing season, 


\section{TABLE IV}

Mean monthly temperature and total rainfall for Lincoln, NE, U.S.A., 1977-1983

\begin{tabular}{|c|c|c|c|c|c|c|c|c|c|c|}
\hline \multirow[t]{2}{*}{ Month } & \multicolumn{7}{|l|}{ Year } & \multicolumn{3}{|c|}{ Normal $^{\mathrm{a}}$} \\
\hline & 1977 & 1978 & 1979 & 1980 & 1981 & 1982 & 1983 & Mean & Max. & Min. \\
\hline \multicolumn{11}{|c|}{ Temperature $\left({ }^{\circ} \mathrm{C}\right)$} \\
\hline April & 13.7 & 10.7 & 9.8 & 11.2 & 14.9 & 9.0 & 7.4 & 11.1 & 17.3 & 4.9 \\
\hline May & 20.2 & 15.6 & 15.4 & 17.1 & 15.4 & 17.4 & 14.5 & 16.8 & 22.8 & 10.7 \\
\hline June & 23.6 & 22.0 & 22.3 & 23.5 & 23.9 & 19.3 & 22.0 & 22.4 & 28.4 & 16.3 \\
\hline July & 27.2 & 24.9 & 23.9 & 27.9 & 25.9 & 26.0 & 27.3 & 25.5 & 31.7 & 19.3 \\
\hline August & 22.4 & 23.8 & 24.0 & 26.0 & 22.4 & 23.4 & 28.6 & 24.3 & 30.4 & 18.2 \\
\hline September & 19.1 & 20.6 & 20.4 & 19.4 & 18.8 & 18.4 & 20.7 & 19.4 & 25.8 & 13.1 \\
\hline October & 10.8 & 11.2 & 12.5 & 11.0 & 11.2 & 12.6 & 12.7 & 12.8 & 19.3 & 6.4 \\
\hline Average & 19.6 & 18.4 & 18.3 & 19.4 & 18.9 & 18.0 & 19.0 & 18.9 & 25.1 & 12.7 \\
\hline \multicolumn{11}{|c|}{ Precipitation ( $\mathrm{mm}$ ) } \\
\hline April & 46 & 183 & 74 & 49 & 48 & 84 & 28 & 65 & 183 & 17 \\
\hline May & 132 & 93 & 75 & 53 & 101 & 139 & 127 & 99 & 226 & 31 \\
\hline June & 25 & 68 & 76 & 76 & 22 & 141 & 195 & 108 & 328 & 16 \\
\hline July & 95 & 128 & 92 & 46 & 82 & 103 & 9 & 90 & 290 & 9 \\
\hline August & 190 & 48 & 71 & 158 & 129 & 218 & 30 & 87 & 218 & 2 \\
\hline September & 154 & 108 & 10 & 8 & 64 & 82 & 66 & 75 & 191 & 7 \\
\hline October & 47 & 37 & 134 & 50 & 23 & 30 & 44 & 48 & 134 & 0 \\
\hline Total & 689 & 665 & 532 & 440 & 469 & 797 & 499 & 573 & 1570 & 83 \\
\hline
\end{tabular}

${ }^{a}$ Normal temperature and rainfall represent 39 -year average for Lincoln, NE, U.S.A.

caused the average growing-season temperature to be near normal for the duration of the experiment.

Precipitation (Table IV) also varied during the study. Seasonal totals (April-October) ranged from 80\% (1980) to $144 \%$ (1982) of the average seasonal total. Months across seasons fluctuated more than seasonal totals. September 1977 had $208 \%$ of normal rainfall, while September 1980 had $11 \%$ of normal. August 1982 had the greatest rainfall $(218 \mathrm{~mm}$ ), and October 1979 had the largest percentage of normal with $312 \%$. September 1980 had the least rainfall ( $8 \mathrm{~mm}$ ); July 1983 and September 1980 both had $11 \%$ of normal rainfall.

The maize-grain yield response to rate of $\mathrm{N}$ fertilization was similar for all treatments (i.e., no treatment $\times \mathrm{N}$ rate interaction). This is contrary to suggestions by Thomas et al. (1973), Bandel et al. (1975) and Moschler and Martens (1975), who indicated that increased $\mathrm{N}$ fertilizer application rates were necessary for no-till to achieve yields equivalent to conventional tillage (plow). However, Thomas and Frye (1984) indicated that $\mathrm{N}$ requirements for plants grown under conventional tillage and no-till were similar if yields were similar. 


\section{TABLE V}

Grain yield ( $\mathrm{Mg} \mathrm{ha}^{-1}$ ) for maize $1977-1983$ for several tillage practices ${ }^{\mathrm{a}}$

\begin{tabular}{llllllll}
\hline Tillage treatment & 1977 & 1978 & 1979 & 1981 & 1982 & 1983 & Mean \\
\hline Plow & 2.11 & 5.41 & $-^{\mathrm{b}}$ & 4.88 & 6.42 & 1.70 & $4.52^{\mathrm{b}}$ \\
Disk & 1.63 & 5.68 & 6.18 & 4.70 & 6.24 & 1.62 & 4.34 \\
Chisel & 1.35 & 4.26 & 6.54 & 5.22 & 6.50 & 1.41 & 4.21 \\
No-till & 1.08 & 4.70 & 6.71 & 5.46 & 6.36 & 1.47 & 4.30 \\
Disk + manure & 1.62 & 4.78 & 6.88 & 4.73 & 7.10 & 1.74 & 4.48 \\
No-till + manure & 2.52 & 5.17 & 6.54 & 4.92 & 6.87 & 0.73 & 4.46 \\
Mean & 1.72 & 5.00 & 6.57 & 4.99 & 6.58 & 1.44 & 4.38 \\
LSD $_{0.05}$ & NS & 0.81 & NS & NS & 0.51 & 0.60 & 0.90 \\
\hline
\end{tabular}

${ }^{a}$ No yield collected during 1980 . Extreme drought caused no yield in all treatments.

${ }^{b}$ Poor stand establishment resulted in no yield-data collection for plow treatment in 1979. Grand mean for plow was calculated by substituting the 1979 overall mean.

Variations in $\mathrm{N}$ requirement were associated with differences in yield potential in their study. Phillips et al. (1980) reported greater grain yields from conventional tillage at low $\mathrm{N}$-fertilizer application rates, but lower conventional-tillage yields at higher $\mathrm{N}$-fertilization rates. They suggested that no-till-grown maize had a more desirable soil environment, especially with respect to soil water, and could, therefore, use the greater amount of applied fertilizer. In the current study, the relatively high organic-carbon content $\left(19 \mathrm{~g} \mathrm{~kg}^{-1}\right)$ of the soil and associated mineralization potential may have masked the interaction of treatment with $\mathrm{N}$ rate (Schepers and Mielke, 1983).

A significant tillage $\times$ year interaction was found for grain yield in this study; therefore, yearly tillage means are presented in Table V. No grain was harvested from any of the treatments in 1980 because of the extreme drought conditions prior to and during flowering (Table II), and because June and July temperatures were above normal by 1.0 and $2.5^{\circ} \mathrm{C}$, respectively. In 1977 yields were low, although the weather was not unusually hot or dry, and rainfall was above normal. However, 1977 followed a very dry 1976 season (similar to 1980), in which no grain was produced. Also, the above-normal rainfall in 1977 occurred largely after the critical pollination and early grain-fill period for maize, with nearly $50 \%$ of the seasonal total received during the months of August and September. Low grain yields in 1983 resulted from a combination of less-than-normal rainfall and higher-than-normal temperatures.

Grain yields in 1977, 1979 and 1981 did not differ significantly among tillage treatments (Table V). In 1978, grain production of treatments with more complete residue incorporation (plow and disk) was significantly greater than that for the chisel treatment, which incoporated little residue but disturbed the soil to a greater extent. During 1982, significant treatment differences resulted 


\section{TABLE VI}

Soil water content and water use ( $\mathrm{mm}$ ) for the 0-1.22 $\mathrm{m}$ depth during growing seasons 1978-1980, Lincoln, NE, U.S.A. ${ }^{a}$

\begin{tabular}{|c|c|c|c|c|c|c|c|c|c|}
\hline \multirow[t]{2}{*}{ Tillage treatment } & \multicolumn{3}{|l|}{1978} & \multicolumn{3}{|l|}{1979} & \multicolumn{3}{|l|}{1980} \\
\hline & Initial & Final & Total & Initial & Final & Total & Initial & Final & Total \\
\hline Plow & 28 & 26 & 312 & 32 & 17 & 259 & 35 & 42 & 232 \\
\hline Disk & 30 & 27 & 313 & 34 & 20 & 258 & 38 & 36 & 241 \\
\hline Chisel & 28 & 26 & 312 & 32 & 13 & 263 & 37 & 59 & 219 \\
\hline No-till & 29 & 26 & 313 & 28 & 16 & 256 & 39 & 39 & 239 \\
\hline Disk + manure & 29 & 26 & 313 & 32 & 19 & 257 & 38 & 39 & 238 \\
\hline \multirow[t]{2}{*}{ No-till + manure } & 29 & 26 & 313 & 32 & 13 & 263 & 39 & 40 & 238 \\
\hline & $\mathrm{NS}^{\mathrm{b}}$ & NS & & NS & NS & & NS & NS & \\
\hline
\end{tabular}

a Total water used is calculated by the difference between initial and final water content plus rainfall between the initial and final measurement dates.

bot significant.

from more grain production with $\left(6.99 \mathrm{Mg} \mathrm{ha}^{-1}\right)$ than without $\left(6.38 \mathrm{Mg} \mathrm{ha}^{-1}\right)$ manure applications. The significant treatment effect in 1983 was caused by the disk + manure treatment producing more grain than the no-till + manure treatment, 1.74 and $0.73 \mathrm{Mg} \mathrm{ha}^{-1}$, respectively. Weed infestations in the notill + manure treatment may have contributed to the lower yield.

Soil water content measurement during the 1978-1980 growing seasons indicated no differences in water use among treatments (Table VI). This was not surprising in 1979 and 1980, because no yield differences were encountered. The low yield of the chisel treatment compared to plow and disk in 1978 was not related to a difference in soil water storage or in water use.

Generally, yield components did not vary among treatments. Kernel weight was particularly consistent over treatments within a given year, varying $<6 \%$ among treatments. Some yearly fluctuations in plant populations were noted, and resulted in differences in ears per unit land area; however, differences were not related to variation in yield. In years with no yield differences, the number of kernels per ear and plant population varied inversely, so the total number of kernels per plant was the same. This combined with similar kernel weights to give similar yields.

The response of maize to $\mathrm{N}$ fertilization rate, although similar across treatments, varied among years in this study (Fig. 1). During 1978, 1982, and 1983, a linear response to $\mathrm{N}$ fertilization rate was found. The response was positive in 1982 and 1983, but negative in 1978. No response to $\mathrm{N}$ fertilization rate was evident in 1981, and 1979 had a quadratic response with the optimum rate near $70 \mathrm{~kg} \mathrm{ha}^{-1}$. These yield patterns (Fig. 1) could represent the response of grain yield to weather conditions in the current or preceding years. The two years 


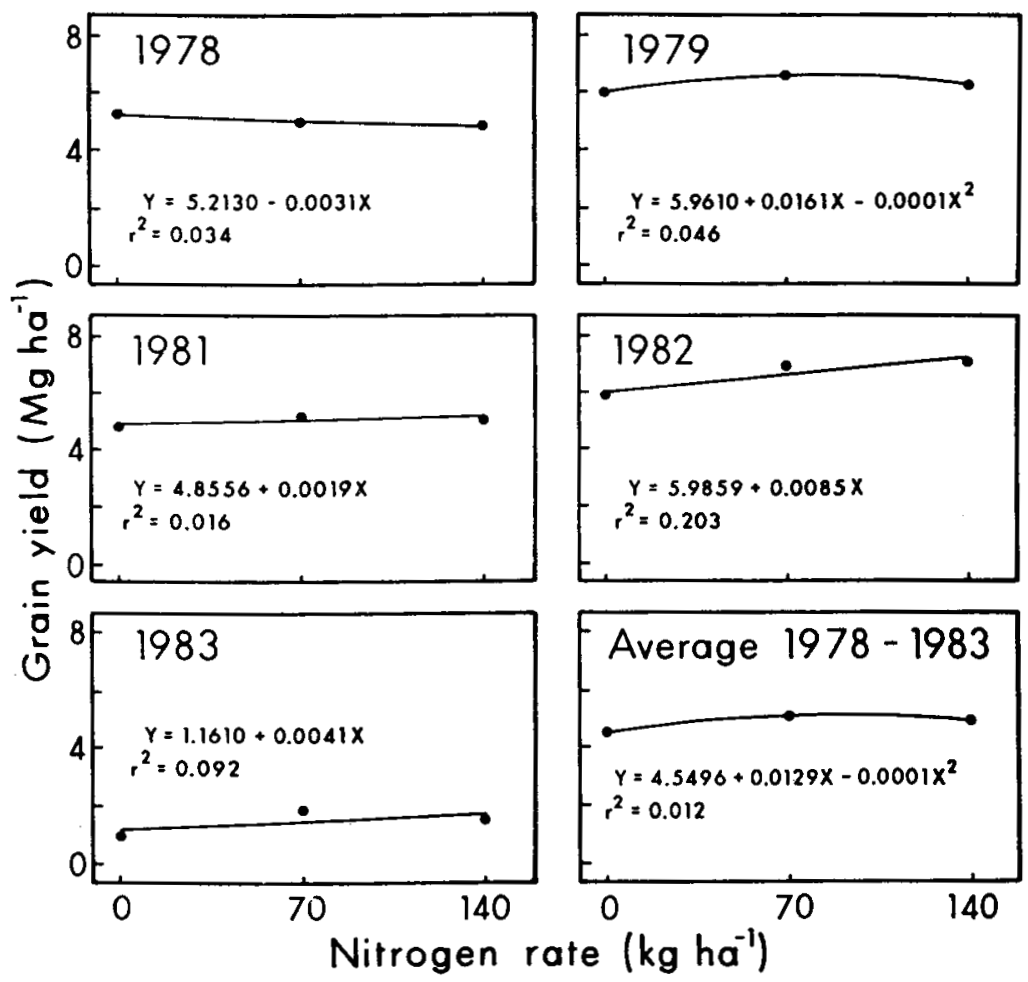

Fig. 1. Maize grain yield response to various nitrogen fertilizer application rates.
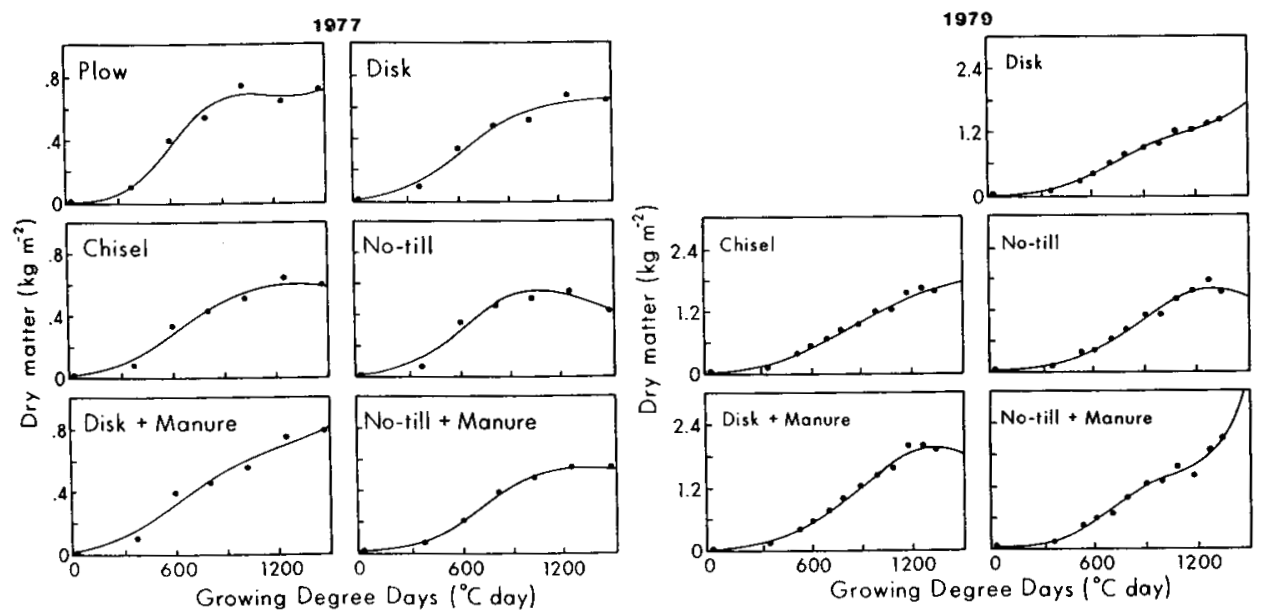

Fig. 2. Dry-matter accumulation for maize grown in 6 tillage treatments during 1977 and 1979. 

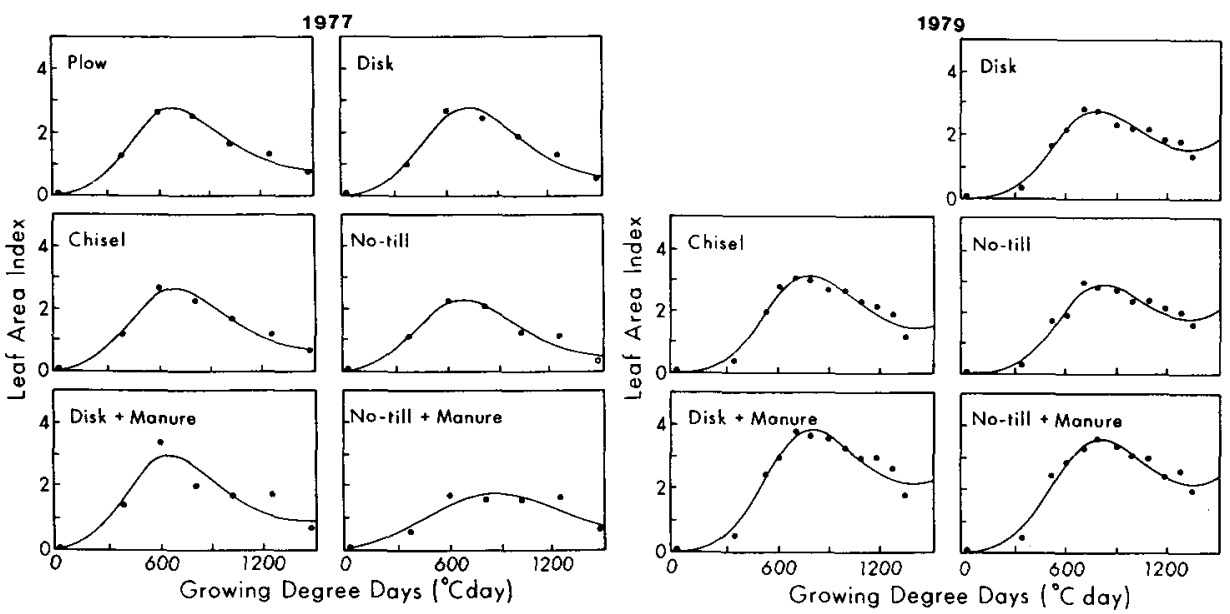

Fig. 3. Leaf-area index for maize grown in 6 tillage treatments during 1977 and 1979.

preceding 1978 were very dry, and, as a result, mineralized $\mathrm{N}$ accumulated in the soil because little was used or leached. Thus, excess available $\mathrm{N}$ in the soil shifted the response curve to the left, showing only the negative portion of the quadratic response. This logic was supported by soil- $\mathrm{N}$ analysis after the 1978 growing season. Total nitrate- $\mathrm{N}$ to a depth of $1.80 \mathrm{~m}$ varied from $85 \mathrm{mg} \mathrm{kg} \mathrm{k}^{-1}$ for the $0 \mathrm{~kg} \mathrm{ha}^{-1} \mathrm{~N}$ treatment to $144 \mathrm{mg} \mathrm{kg}^{-1}$ for the $140 \mathrm{~kg} \mathrm{ha}^{-1} \mathrm{~N}$ treatment. The other years were all slight modifications of the general quadratic relationship between $\mathrm{N}$ fertilization rate and grain yield. Optimum grain yield, over all years, was obtained at $90 \mathrm{~kg} \mathrm{ha}^{-1} \mathrm{~N}$.

The patterns of both dry-matter accumulation (Fig. 2) and leaf area (Fig. 3 ) were very similar for all tillage treatments (Table VII). During 1977, a dry season, maximum dry matter was less than that in 1979, a near-normal precipitation year. Differences in climate between the years had less effect on LAI than on dry-matter production. Final LAI (at physiological maturity) was much less in 1977 than 1979. This difference was caused by greater leaf senescence at the base as well as in the top of the canopy. Severely stressed leaf tissue was frequently blown from the plants by wind.

Growth analysis functions of CGR and NAR (based on degree days; Russelle et al., 1984) revealed no consistent trends among the various tillage treatments over the two seasons investigated. However, LAD ('Table VIII) differed among the treatments and between years. Again, the better growing conditions of 1979 were reflected in a greater LAD. The LAD values were highly correlated with grain yield $\left(r=0.47^{* * *}\right)$. This supports the importance of duration and extent of photosynthetic tissue in determining crop yield (Evans et al., 1975; Gardner et al., 1985).

The results of these investigations indicate the relative importance of yearly 


\section{TABLE VII}

Coefficients of determination and regression for the formula, $Y=\exp \left(b_{0}+b_{1} x+b_{2} x^{2}+b_{3} x^{3}\right)$, where $Y$ is dry matter or leaf area index and $x$ is growing degree days $\left({ }^{\circ} \mathrm{C}\right.$ day), for curves presented in Figs. 2 and 3

\begin{tabular}{|c|c|c|c|c|c|c|}
\hline Year & $\begin{array}{l}\text { Tillage } \\
\text { treatment }\end{array}$ & $b_{0}$ & $\begin{array}{l}b_{1} \\
\times 10^{-2}\end{array}$ & $\begin{array}{l}b_{2} \\
\times 10^{-5}\end{array}$ & $\begin{array}{l}b_{3} \\
\times 10^{-9}\end{array}$ & $r^{2}$ \\
\hline \multicolumn{7}{|c|}{ Dry matter $\left(\mathrm{kg} \mathrm{ha}^{-1}\right)$} \\
\hline \multirow[t]{6}{*}{1977} & Plow & 0.68 & 1.52 & -1.30 & 3.67 & 0.77 \\
\hline & Disk & 2.30 & 0.91 & -0.68 & 1.70 & 0.84 \\
\hline & Chisel & 2.53 & 0.80 & -0.54 & 1.21 & 0.72 \\
\hline & No-till & 1.77 & 1.08 & -0.83 & 1.99 & 0.71 \\
\hline & Disk + manure & 2.92 & 0.75 & -0.54 & 2.42 & 0.80 \\
\hline & No-till + manure & 1.06 & 1.13 & -0.81 & 1.92 & 0.66 \\
\hline \multicolumn{7}{|c|}{ Leaf area index } \\
\hline \multirow[t]{6}{*}{1977} & Plow & -3.42 & 1.51 & -1.61 & 4.98 & 0.75 \\
\hline & Disk & -3.60 & 1.50 & -1.50 & 4.25 & 0.83 \\
\hline & Chisel & -3.36 & 1.49 & -1.59 & 4.87 & 0.76 \\
\hline & No-till & -3.06 & 1.32 & -1.38 & 3.99 & 0.79 \\
\hline & Disk + manure & -2.90 & 1.44 & -1.62 & 5.24 & 0.68 \\
\hline & No-till+manure & -2.38 & 0.75 & -0.57 & 1.05 & 0.49 \\
\hline \multicolumn{7}{|c|}{ Dry matter $\left(\mathrm{kg} \mathrm{ha}^{-1}\right)$} \\
\hline \multirow[t]{5}{*}{1979} & Disk & 0.66 & 1.47 & -1.18 & 3.32 & 0.86 \\
\hline & Chisel & 2.90 & 0.79 & -0.47 & 1.01 & 0.77 \\
\hline & No-till & 2.76 & 0.69 & -0.25 & -0.07 & 0.86 \\
\hline & Disk + manure & 3.25 & 0.65 & -0.24 & 0.00 & 0.85 \\
\hline & No-till+manure & -0.39 & 1.97 & -1.77 & 5.49 & 0.80 \\
\hline \multicolumn{7}{|c|}{ Leaf area index } \\
\hline \multirow[t]{5}{*}{1979} & Disk & -5.87 & 2.18 & -2.20 & 6.90 & 0.89 \\
\hline & Chisel & -5.17 & 1.96 & -1.95 & 5.81 & 0.80 \\
\hline & No-till & -6.12 & 2.20 & -2.16 & 6.68 & 0.91 \\
\hline & Disk + manure & -4.80 & 1.89 & -1.84 & 5.56 & 0.90 \\
\hline & No-till+manure & -4.83 & 1.89 & -1.87 & 5.75 & 0.84 \\
\hline
\end{tabular}

climatic variation and tillage practice in determining growth and yield in dryland maize. In every parameter evaluated, the influence of climate was greater than that of tillage practice. These data indicated that the water conservation potential of reduced-tillage practices was not sufficient to improve maize yield. Also, contrary to some earlier reports (Thomas et al., 1973; Bandel et al., 1975; Moschler and Martens, 1975), it does not appear that, in this climatic zone, maize produced without tillage requires more $\mathrm{N}$ fertilizer. 


\section{TABLE VIII}

Leaf area duration (LAD) of maize grown under various tillage during 1977 and 1979

\begin{tabular}{|c|c|c|c|c|}
\hline \multirow{2}{*}{$\begin{array}{l}\text { Tillage } \\
\text { treatment }\end{array}$} & & \multicolumn{2}{|c|}{$\operatorname{LAD}(M)^{a}$} & \multirow[t]{2}{*}{ Mean } \\
\hline & & 1977 & 1979 & \\
\hline Plow & & 2124 & $-{ }^{b}$ & $--^{b}$ \\
\hline Disk & & 2093 & 1990 & 2042 \\
\hline Chisel & & 2057 & 2257 & 2157 \\
\hline No-till & & 1773 & 2081 & 1927 \\
\hline Disk + manure & & 2327 & 2853 & 2590 \\
\hline No-till+manure & & 1643 & 2704 & 2174 \\
\hline Mean & & 2003 & 2377 & 2173 \\
\hline \multicolumn{5}{|l|}{$\operatorname{LSD}_{0.05}{ }^{c}$} \\
\hline Tillage & 254 & & & \\
\hline Year & 285 & & & \\
\hline
\end{tabular}

${ }^{a}$ LAD (M) has units of modified growing degree days ( ${ }^{\circ} \mathrm{C}$ day).

bNo data collected on plow treatment during 1979.

${ }^{c}$ Year $\times$ tillage interaction not significant.

\section{CONCLUSIONS}

(1) Year-to-year variation in climate (rainfall and temperature) influenced growth parameters and yield more than tillage treatments.

(2) Water conservation potential of reduced-tillage practices was not sufficient to improve grain yield.

(3) In contrast to some earlier reports, maize produced without tillage did not require more $\mathrm{N}$ fertilizer.

\section{REFERENCES}

Bandel, V.A., Dzienia, S., Stanford, G. and Legg, J.O., 1975. N behavior under no-till vs. conventional corn culture. I. First-year results using unlabeled N fertilizer. Agron. J., 67: 782-786.

Bauder, J., 1984. Conservation tillage information center. Crops Soils, 36: 5-6.

Baeumer, K. and Bakermans, W.A.P., 1973. Zero tillage. Adv. Agron., 25: 77-123.

Blevins, R.L., Cook, D., Phillips, S.H. and Phillips, R.E., 1971. Influence of no-tillage on soil moisture. Agron. J., 63: 593-596.

Evans, L.T., Wardlow, I.F. and Fischer, R.A., 1975. Wheat. In: L.T. Evans (Editor), Crop Physiology: Some Case Histories. Cambridge Univ. Press, pp. 101-149.

Gardner, F.P., Pearce, R.B. and Mitchell, R.L., 1985. Physiology of Crop Plants. Iowa State Press, Ames, IA.

Harrold, L.L. and Edwards, W.M., 1972. A severe watershed test of no-tillage corn. J. Soil Water Conserv., 27: 30.

Hunt, R., 1978. Plant Growth Analysis. Edward Arnold, London, 67 pp.

Johnson, M.D., Lowry, B. and Daniel, T.C., 1984. Soil moisture regimes of three conservation tillage systems. Trans. Am. Soc. Agric. Eng., 27: 1385-1390, 1395.

Jones, J.N., Jr., Moody, J.E., Shear, G.M., Moschler, W.W. and Lillard, J.H., 1968. The no-tillage system for corn (Zea mays L.). Agron. J., 60: 17-20. 
Mielke, L.N., Wilhelm, W.W., Richards, K.A. and Fenster, C.R., 1984. Soil physical characteristics of reduced tillage in a wheat-fallow system. Trans. Am. Soc. Agric. Eng., 27: 1724-1728.

Moschler, W.W. and Martens, D.C., 1975. Nitrogen, phosphorus, and potassium requirements in no-tillage and conventionally tilled corn. Soil Sci. Soc. Am. Proc., 39: 886-891.

Olson, T.C. and Shoeberl, L.S., 1970. Corn yields, soil temperature, and water use with four tillage methods in the Western Corn Belt. Agron. J., 62: 229-231.

Onstad, C.A., 1972. Soil and water losses affected by tillage practices. Trans. Am. Soc. Agric. Eng., 15: $287-289$.

Phillips, R.E., Blevins, R.L., Thomas, G.W., Frye, W.W. and Phillips, S.H., 1980. No-tillage agriculture. Science, 208: 1108-1113.

Russelle, M.P., Wilhelm, W.W., Olson, R.A. and Power, J.F., 1984. Growth analysis based on degree days. Crop Sci., 24: 28-32.

Schepers, J.S. and Mielke, L.N., 1983. Nitrogen fertilization, mineralization and leaching under irrigation in the Midwest. In: R. Lowrance, R. Todd, L. Asmussen and R. Leonard (Editors), Nutrient Cycling in Agricultural Ecosystems, Univ. Georgia Coll. Agric. Spec. Publ. No. 5, pp. $325-334$.

Shanholtz, B.O. and Lillard, J.H., 1969. Tillage systems effects on water use efficiency. J. Soil Water Conserv., 24: 186-189.

SAS, 1985. SAS User's Guide: Statistics, Version 5 Edition. SAS Institute, Inc., Cray, NC, 956 pp.

Thomas, G.W., Blevins, R.L., Phillips, R.E. and McMahon, M.A., 1973. Effects of a killed sod mulch on nitrate movement and corn yield. Agron. J., 65: 736-739.

Thomas, G.W. and Frye, W.W., 1984. Fertilization and liming. In: R.E. Phillips and S.H. Phillips (Editors), No-Tillage Agriculture: Principles and Practices. Van Nostrand Reinhold Co., NY, pp. 87-126.

Triplett, G.B., Jr., 1982. Tillage and crop productivity. In: M. Rechcigl, Jr. (Editor), CRC Handbook of Agricultural Productivity. Vol. I. Plant Productivity. CRC Press, Inc., Boca Raton, FL, pp. 251-262.

Van Doren, D.M., Jr. and Triplett, G.B., Jr., 1973. Mulch and tillage relationships in corn culture. Soil Sci. Soc. Am. Proc., 37: 766-769. 